U.S. Geological Survey National Assessment of Oil and Gas Resources Project

\title{
Map of Assessed Continuous (Unconventional) Oil Resources in the United States, 2014
}
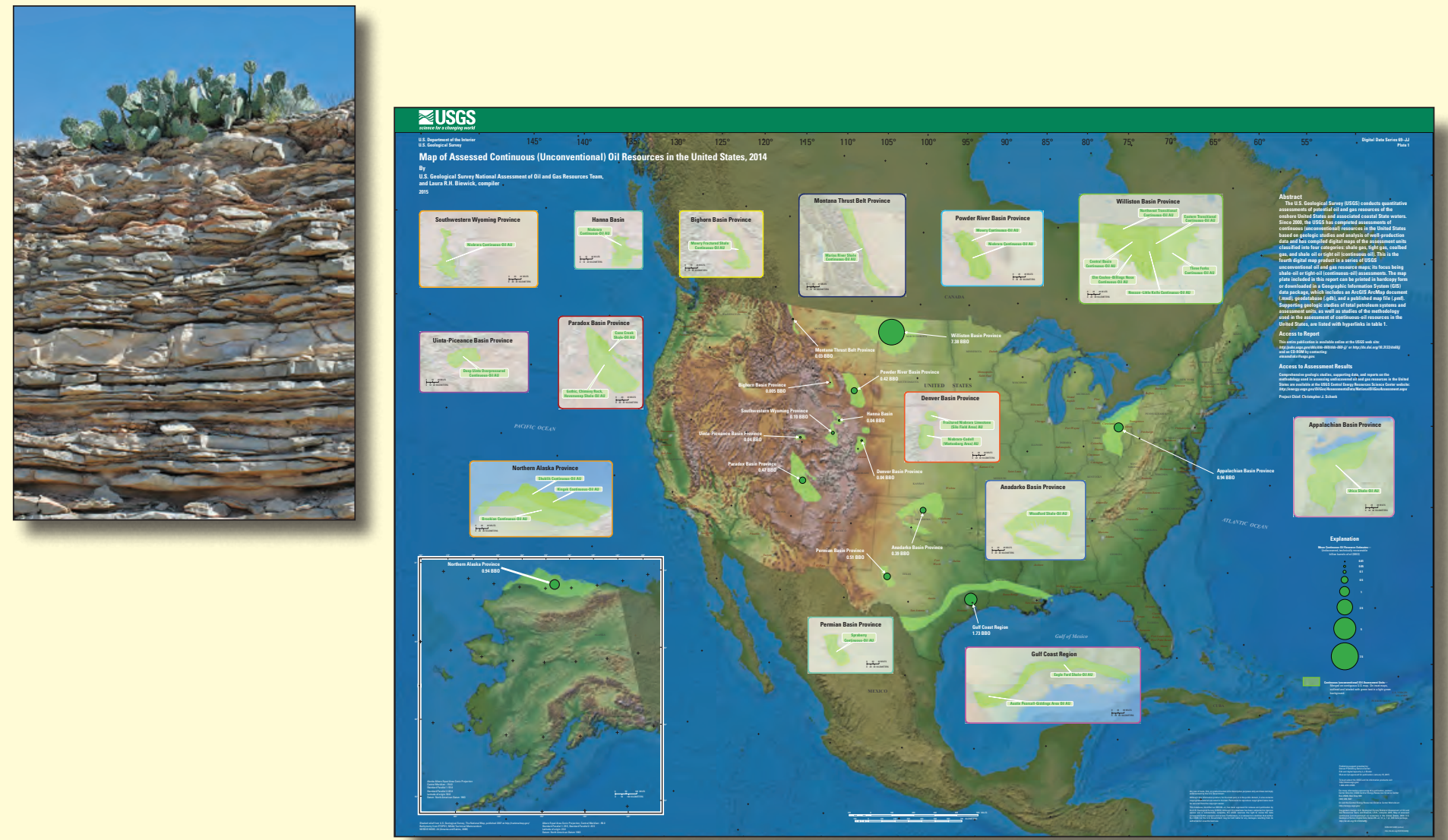

Digital Data Series 69-JJ 
Cover. Basal Boquillas Limestone (Eagle Ford equivalent in west Texas), just above the contact with the Buda limestone, taken along US 90, approximately 4.1 miles north of the Pecos River US 90 Highway bridge. Photo by Jim Coleman (USGS). 


\section{Map of Assessed Continuous (Unconventional) Oil Resources in the United States, 2014}

By U.S. Geological Survey National Assessment of Oil and Gas Resources Team, and Laura R.H. Biewick, compiler

U.S. Geological Survey National Assessment of Oil and Gas Resources Project

Digital Data Series 69-JJ 


\title{
U.S. Department of the Interior SALLY JEWELL, Secretary
}

\section{U.S. Geological Survey Suzette M. Kimball, Acting Director}

\author{
U.S. Geological Survey, Reston, Virginia: 2015
}

For more information on the USGS - the Federal source for science about the Earth, its natural and living resources, natural hazards, and the environment, visit http://wWw.usgs.gov or call 1-888-ASK-USGS

For an overview of USGS information products, including maps, imagery, and publications, visit http://WwW.usgs.gov/pubprod

To order this and other USGS information products, visit http://store.usgs.gov

Any use of trade, firm, or product names is for descriptive purposes only and does not imply endorsement by the U.S. Government.

Although this information product, for the most part, is in the public domain, it also may contain copyrighted materials as noted in the text. Permission to reproduce copyrighted items must be secured from the copyright owner.

Suggested citation:

U.S. Geological Survey National Assessment of Oil and Gas Resources Team, and Biewick, L.R.H., compiler, 2015, Map of assessed continuous (unconventional) oil resources in the United States, 2014: U.S. Geological Survey Digital Data Series 69-JJ, 14 p., 1 pl., GIS data package, http://dx.doi.org/10.3133/ds069jj. 


\section{Contents}

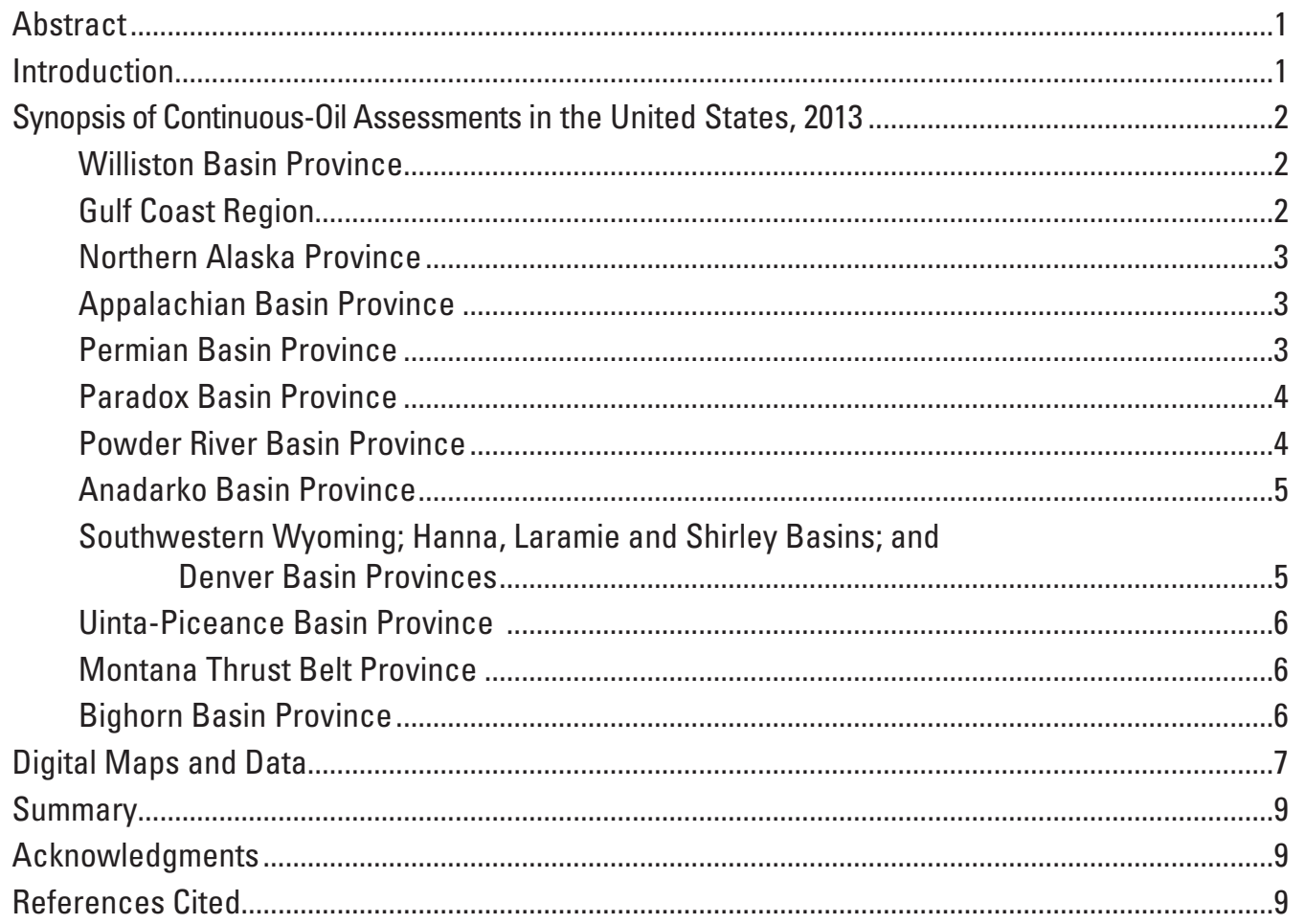

\section{Plate}

1. Map of assessed continuous (unconventional) oil resources in the

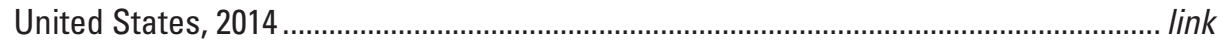

\section{Figure}

1. Map graphic links to the continuous-oil resources hardcopy map .................................8

\section{Table}

1. Publication access table-Hyperlinks to USGS continuous-oil assessment publications and web pages 


\section{Conversion Factors}

Inch/Pound to SI

\begin{tabular}{lcl}
\hline \multicolumn{1}{c}{ Multiply } & By & To obtain \\
\hline & Length & \\
\hline inch (in.) & 25.4 & millimeter $(\mathrm{mm})$ \\
\hline & Area & \\
\hline square mile $\left(\mathrm{mi}^{2}\right)$ & 2.590 & square kilometer $\left(\mathrm{km}^{2}\right)$ \\
\hline & Volume & \\
\hline $\begin{array}{l}\text { cubic foot }\left(\mathrm{ft}^{3}\right) \\
\text { barrel }(\mathrm{bbl}), \text { petroleum, } \\
1 \text { barrel =42 gal. }\end{array}$ & 0.02832 & cubic meter $\left(\mathrm{m}^{3}\right)$ \\
\hline
\end{tabular}

SI to Inch/Pound

\begin{tabular}{lcl}
\hline Multiply & By & To obtain \\
\hline & Length & \\
\hline millimeter $(\mathrm{mm})$ & 0.3937 & inch (in.) \\
\hline & Volume & \\
\hline cubic meter $\left(\mathrm{m}^{3}\right)$ & 35.31 & cubic foot $\left(\mathrm{ft}^{3}\right)$ \\
\hline
\end{tabular}

Temperature in degrees Celsius $\left({ }^{\circ} \mathrm{C}\right)$ may be converted to degrees Fahrenheit $\left({ }^{\circ} \mathrm{F}\right)$ as follows:

$$
{ }^{\circ} \mathrm{F}=\left(1.8 \times{ }^{\circ} \mathrm{C}\right)+32
$$

Temperature in degrees Fahrenheit $\left({ }^{\circ} \mathrm{F}\right)$ may be converted to degrees Celsius $\left({ }^{\circ} \mathrm{C}\right)$ as follows:

$$
{ }^{\circ} \mathrm{C}=\left({ }^{\circ} \mathrm{F}-32\right) / 1.8
$$




\title{
Map of Assessed Continuous (Unconventional) Oil Resources in the United States, 2014
}

\author{
By U.S. Geological Survey National Assessment of Oil and Gas Resources Team, \\ and Laura R.H. Biewick, compiler
}

\begin{abstract}
The U.S. Geological Survey (USGS) conducts quantitative assessments of potential oil and gas resources of the onshore United States and associated coastal State waters. Since 2000, the USGS has completed assessments of continuous (unconventional) resources in the United States based on geologic studies and analysis of well-production data and has compiled digital maps of the assessment units classified into four categories: shale gas, tight gas, coalbed gas, and shale oil or tight oil (continuous oil). This is the fourth digital map product in a series of USGS unconventional oil and gas resource maps; its focus being shale-oil or tight-oil (continuous-oil) assessments. The map plate included in this report can be printed in hardcopy form or downloaded in a Geographic Information System (GIS) data package, which includes an ArcGIS ArcMap document (.mxd), geodatabase (.gdb), and a published map file (.pmf). Supporting geologic studies of total petroleum systems and assessment units, as well as studies of the methodology used in the assessment of continuous-oil resources in the United States, are listed with hyperlinks in table 1. Assessment results and geologic reports are available at the USGS website http://energy.usgs.gov/ OilGas/AssessmentsData/NationalOilGasAssessment.aspx.
\end{abstract}

\section{Introduction}

The U.S. Geological Survey (USGS) provides assessments of the oil and natural gas endowment of the United States (U.S.). Prioritized assessment results, as part of the Energy Policy and Conservation Act (EPCA) of 2000 (Public Law 106-469, http://www.gpo.gov/fdsys/pkg/ PLAW-106publ469/html/PLAW-106publ469.htm) and the current National Oil and Gas Assessment, are available at the USGS Energy Resources Program website (U.S. Geological Survey, 2013). The assessments are based on the geologic elements and petroleum processes used to define a total petroleum system (TPS). An advantage of the total petroleum system approach is that by incorporating the assessment unit (AU) within a petroleum system, relations between elements and processes such as source rock, hydrocarbon generation, migration, and trapping units and mechanisms can be examined (Dubiel, 2003). Continuous-oil accumulations differ from conventional accumulations in that they are not significantly affected by hydrodynamics, there generally is no downdip oil/water contact, they are abnormally pressured, production is independent of structural closure, and conventional methods of assessing sizes and numbers of accumulations are not appropriate (Klett and others, 2000). The U.S. Geological Survey Oil and Gas Assessment Team (2012) describes estimated ultimate recovery (EUR) distributions that were calculated for each continuous (unconventional) AU, based on geologic studies and decline-curve analysis of well-production data from hundreds to thousands of wells per AU. Each AU was further subdivided into distributions of potential well-drainage areas. The EUR distribution used for each assessment calculation was specifically designed for undrilled well-drainage areas and for the productive capacities of those areas (U.S. Geological Survey Oil and Gas Assessment Team, 2012). Using this geologic and engineering framework, the USGS defined continuous-oil AUs in 14 geologic provinces that cover parts of 17 states. The provinces include: Northern Alaska; Uinta-Piceance Basin; Paradox Basin; Montana Thrust Belt; Hanna, Laramie and Shirley Basins; Williston Basin; Powder River Basin; Big Horn Basin; Southwestern Wyoming; Denver Basin; Permian Basin; Gulf Coast Basins; Anadarko Basin; and Appalachian Basin. The continuous-oil assessment units defined in these geologic provinces encompass parts of Alaska, Colorado, Utah, Arizona, New Mexico, Montana, Wyoming, North Dakota, Texas, Louisiana, Mississippi, Oklahoma, Kansas, Ohio, Pennsylvania, West Virginia, and New York (plate 1) and are described in detail by USGS investigators, as listed in table 1 . 


\section{Synopsis of Continuous-0il Assessments in the United States, 2013}

The U.S. uses about 22 percent of total world petroleum consumption, at approximately 7.0 billion barrels (19.18 million barrels per day) of refined petroleum products and biofuels annually (Energy Information Administration, 2012a). In 2012, the U.S. produced 11.1 million barrels per day (Energy Information Administration, 2012b). The Bakken region of North Dakota and Montana, in one of the largest oil-producing regions in the U.S., shows total wellhead output topping 1 million barrels of oil per day in January 2014 (Energy Information Administration, 2013). The following is a synopsis of geologic findings by the USGS scientists who assessed continuous-oil resources in the U.S. listed in descending order according to mean undiscovered, technically recoverable, continuous-oil resources. More detailed supporting geologic studies, referenced within, can be found at the USGS Energy Resources Program website at http://energy.usgs.gov/OilGas/AssessmentsData/ NationalOilGasAssessment.aspx.

\section{Williston Basin Province (Gaswirth and others, 2013)}

Oil production from the Upper Devonian and Lower Mississippian Bakken Formation was discovered by Amerada Hess with the completion of the H.O. Bakken No.1 well in sec. 12, T. 157 N., R. 95 W., Williams County, North Dakota in 1951 (Nordquist, 1953; Johnson, 2001; Bottjer and others, 2011). Robinson and others (2011) recognized that the ability to extract oil from the Bakken Formation at Elm Coulee field in eastern Montana as a transformative event. They explain that at Elm Coulee field a known oil resource was converted into reserves by the application of innovative horizontal drilling and completion technology (Robinson and others, 2011). Within a few years, the discovery of the Parshall field at the eastern pinchout of the Bakken Formation in North Dakota took place, after which drilling expanded rapidly to the north and south and then to the west (Robinson and others, 2011). After more than 4,000 additional wells were drilled, providing significant geologic data about the Bakken and Three Forks Formations, Gaswirth and others (2013) updated and extended the 2008 USGS assessment of the Bakken Formation (Pollastro and others, 2008) and also assessed the Three Forks Formation. Four members of the Bakken Formation were described by Gaswirth and others (2013), including the upper and lower organic-rich black shales, which are the primary source rocks with present-day total organic carbon (TOC) values from $<1$ weight percent to 35 weight percent (Lillis, 2013). The Three Forks Formation reaches a maximum thickness of 270 feet in the central portion of the basin (Bottjer and others, 2011) and is divided into lower and upper units, with variable oil saturations (Gaswirth and others, 2013). One of the most prolific onshore petroleum systems in the continental U.S., the Bakken and Three Forks Formations in the Williston Basin are the largest continuous oil accumulation assessed by the USGS to date (plate 1, and U.S. Geological Survey Oil and Gas Assessment Team, 2013). The Bakken petroleum system is a world-class petroleum resource representing the large upside to be gained by understanding unconventional petroleum systems (Stroud and Sonnenberg, 2011). In 2013, the USGS assessment of continuous-oil resources estimated mean undiscovered volumes of 7.38 billion barrels of oil (BBO), 6.7 trillion cubic feet of associated natural gas (TCFG), and 527 million barrels of natural gas liquids (MMBNGL) in the Bakken and Three Forks Formations in the Williston Basin Province of Montana and North Dakota (Gaswirth and others, 2013). Supporting geologic studies of the Bakken and Three Forks Formations and the methodology used in the assessment are in progress, and can be found at the USGS Energy Resources Program website at http://energy.usgs.gov/OilGas/ AssessmentsData/NationalOilGasAssessment.aspx.

\section{Gulf Coast Region (Dubiel and others, 2011)}

One of the primary hydrocarbon-producing provinces of the U.S., and a major hydrocarbon-producing area of the world, is the Gulf of Mexico (Gulf Coast) region. Recent discoveries of continuous oil in the Gulf Coast region are some of the largest in the U.S. and have led to additional exploration throughout the onshore Gulf region. In 2010, the USGS completed an assessment of the undiscovered oil and gas resources in Jurassic and Cretaceous strata of the onshore areas and State waters of the Gulf Coast (Dubiel and others, 2011). The USGS defined the Upper Jurassic-CretaceousTertiary Composite TPS and thirty-four defined AUs, with two AUs containing undiscovered, technically recoverable continuous oil in Upper Cretaceous strata. The continuous-oil resources reside in the Eagle Ford Shale and the Austin Chalk in Texas, and the marine shale of the Tuscaloosa Formation in Louisiana (Dubiel and others, 2012; Pearson, 2012). The Eagle Ford Shale is a dominant source rock in the onshore Gulf region, and Dubiel and others (2012) defined the continuous Eagle Ford Shale-Oil AU by thermal maturity values within the Eagle Ford Shale and the Tuscaloosa marine shale ranging from 0.6 to 1.2 percent vitrinite reflectance $\left(R_{0}\right)$. The Upper Cretaceous Austin Chalk is a historically well-known onshore oil and gas play that extends across south-central Texas into southern Louisiana. Pearson (2012) found that chalk of the Austin Pearsall-Giddings Area Oil AU produces oil and gas in a continuous reservoir, and traditional trap styles such as anticlines and faults are not essential for the accumulation and production of oil and gas. Pearson and others (2011) recognized that the underlying Upper Cretaceous Eagle Ford Shale is the principal source rock for Austin Chalk production. They noted that a continuous classification is common for 
reservoirs like the Austin because the extremely low matrix porosity and permeability provide a means for trapping oil and gas accumulations that have diffuse boundaries and lack obvious traps and seals (Pearson, 2012). The USGS assessment of continuous-oil resources in Cretaceous strata of the Gulf Coast region estimated a mean of 1.73 BBO, 3 TCFG, and 140 MMBNGL (Dubiel and others, 2011; Pearson and others, 2011; Dubiel and others, 2012). Supporting geologic studies of the Gulf Coast region assessments are in progress, and 2010 assessment results of Jurassic and Cretaceous strata of the Gulf Coast are available at the USGS Energy Resources Program website at http://energy.usgs.gov/OilGas/ AssessmentsData/NationalOilGasAssessment.aspx.

\section{Northern Alaska Province (Houseknecht and others, 2012)}

The Northern Alaska Province encompasses the Alaska North Slope, which is one of the remaining petroleum exploration frontiers. It is geologically complex having evolved through the tectonic stages of passive margin, rift, foreland basin, and foreland fold and thrust belt (Schenk and others, 2011). Houseknecht and others (2012) describe the potential for unconventional oil and gas resources in three North Slope source rocks including the: (1) informal Brookian shale (Cretaceous), (2) Kingak Shale (Jurassic and Cretaceous), and (3) Shublik Formation (Triassic). Houseknecht and others (2012) recognized that each of these stratigraphic units generated oil and gas that migrated into conventional accumulations, and that all three likely retained oil and gas. Houseknecht and others (2012) explain how the Alaska North Slope assessment represents an unexplored frontier for shale-oil and shale-gas resources, in that no attempt has been made to produce oil or gas directly from the source rocks. The presence of brittle lithologies in which natural fractures are common in both the Shublik and Brookian source rocks is an important consideration. The Kingak, however, is mostly clayrich shale. Because of the large range of uncertainty associated with estimating undiscovered, continuous-oil resources in these source rocks, Houseknecht and others (2012) used shale-oil and shale-gas formations in the lower 48 states as geologic and engineering analogs to define assessment units, and emphasized the 95- to 5-percent probability range in their estimates of shale-oil resources in northern Alaska. The USGS estimates of potential, technically recoverable shale-oil resources in northern Alaska range from zero to $2 \mathrm{BBO}$, from zero to $3.2 \mathrm{TCFG}$, and from zero to $83 \mathrm{MMBNGL}$ (Houseknecht and others, 2012). Supporting reports on geology and methodology used in the Alaska North Slope assessment are in progress. Assessment results and related reports are available at the USGS Energy Resources Program website at http://energy.usgs.gov/OilGas/AssessmentsData/ NationalOilGasAssessment.aspx.

\section{Appalachian Basin Province (Kirschbaum and others, 2012)}

The Utica-Lower Paleozoic TPS was identified in the 2002 USGS assessment of undiscovered, technically recoverable oil and gas resources in the Appalachian Basin province (Milici and others, 2003). The Utica Shale and equivalent units of thin black shale in the uppermost part of the Trenton Limestone (Group) are the primary source rocks in the Utica-Lower Paleozoic TPS (Ryder, 2008). In 2012, the USGS assessed unconventional oil and gas resources of the Middle and Upper Ordovician Utica Shale and adjacent units in the Appalachian Basin Province (Kirschbaum and others, 2012). Kirschbaum and others (2012) defined the Utica Shale-Oil AU as the area south of the United States-Canadian border where oil was generated and occupies matrix porosity and organic porosity in the Utica Shale and adjacent organic-rich shale. The thermal window for oil was based on a conodont alteration index (CAI) between 1 and 2 (Repetski and others, 2008) and TOC content greater than 1 weight percent (Wallace and Roen, 1989; Ryder, 2008) in the area north of where the shale changes facies into carbonates (Kirschbaum and others, 2012). The Utica has little history of production, therefore Kirschbaum and others (2012) supplemented production data with analog data from the Devonian Marcellus Shale, Cretaceous Eagle Ford Shale, and Cretaceous Niobrara Formation. The assessed undiscovered, technically recoverable continuous oil resources for the Utica Shale-Oil AU, which contains the Ordovician Utica Shale and black shales of the Point Pleasant Shale of the Appalachian Basin Province resulted in estimated volumes ranging from 0.6 to $1.39 \mathrm{BBO}$, with an estimated mean continuous oil resource of $0.94 \mathrm{BBO}$, a mean of $0.94 \mathrm{TCFG}$, and a mean of 9 MMBNGL; (see Kirschbaum and others, 2012). Supporting geologic studies of the Utica Shale and assessment units, and reports on the assessment methodology used, can be found at the USGS Energy Resources Program website at http://energy.usgs.gov/OilGas/AssessmentsData/ NationalOilGasAssessment.aspx.

\section{Permian Basin Province (Schenk and others, 2008)}

The Permian Basin is a large structural basin filled with Paleozoic and younger sediments encompassing about 82,000 square miles $\left(\mathrm{mi}^{2}\right)$ in west Texas and southeastern New Mexico (Robinson, 1988). It acquired its present structural form by Early Permian time and was further accentuated by tectonic activity and downwarping during the Permian and Triassic Periods (Robinson, 1988). Permian rocks account for a large percentage of the oil and gas found in the Permian Basin. Robinson (1988) states that the fractured siltstone in the Spraberry Formation of the Midland Basin has a very 
low recovery factor, although the volume of oil in-place is the largest of any single Permian pool. Handford (1981) recognized that thin black shales are widely distributed in the Spraberry-Dean system, and generally contain 1 to 3 percent TOC. Technologies like hydraulic fracturing and horizontal drilling have ignited new exploration in older plays like the Spraberry. Schenk and others (2008) defined the Paleozoic Composite Total Petroleum System, and assessed the undiscovered oil and gas potential of the Permian Basin Province of west Texas and southeastern New Mexico. For the first time, the USGS defined continuous assessment units in the Permian Basin Province including the Spraberry Continuous Oil AU in the Midland Basin. For undiscovered continuous oil resources, the estimated mean is $0.51 \mathrm{BBO}, 258 \mathrm{BCFG}$, and 26 MMBNGL (Schenk and others, 2008). Supporting geologic studies of the composite total petroleum system and assessment units, as well as the methodology used in the Permian Basin Province assessment are in progress. Assessment results are available at the USGS Energy Resources Program website at http://energy.usgs.gov/OilGas/AssessmentsData/ NationalOilGasAssessment.aspx.

\section{Paradox Basin Province (Whidden, 2012)}

The Paradox Basin is a tectonic depression in southeastern Utah, southwestern Colorado, northwestern New Mexico, and northeastern Arizona that formed during the Pennsylvanian Period in response to large intraplate stresses that have been attributed to the collision of Gondwana and Laurentia (Barbeau, 2003; Kluth and DuChene, 2009). The basin is generally defined by the geographic extent of halite deposited within the Middle Pennsylvanian Paradox Formation (Dubiel and others, 1996). The Paradox Basin began to subside in the Middle Pennsylvanian and is associated with uplift of the Uncompahgre Highlands of the Ancestral Rocky Mountains (Dubiel and others, 1996). As much as 9,000 ft of Middle and Upper Pennsylvanian evaporites, shale, and limestone, and at least $6,000 \mathrm{ft}$ of Permian marine and continental strata are present in the basin (Dubiel and others, 1996). Nuccio and Condon (1996) found that the Ismay-Desert Creek interval and Cane Creek cycle of the Alkali Gulch interval of the Paradox Formation contain excellent organic-rich source rocks having TOC ranging from 0.5 to 11.0 weight percent. The source rocks in both intervals contain Types I, II, and III kerogen and are potential source rocks for both oil and gas (Nuccio and Condon, 1996). In 2011, the USGS defined the Paradox Formation TPS as hydrocarbons sourced from Middle Pennsylvanian (Desmoinesian) black dolomitic shales of the Paradox Formation (Whidden and others, 2012). Whidden and others (2012) described the interbedded salt and black shales that were deposited close to the northern margin of the basin along with clastics shed off the Uncompahgre uplift. Whidden and others (2012) explained that penesaline and normal-marine carbonates developed along the gently-dipping southwest basin margin and interfingered with the salt and black shales. Two continuous-oil AUs: (1) the Cane Creek Shale-Oil AU, and (2) the Gothic, Chimney Rock, Hovenweep Shale-Oil AU were defined as part of the Paradox Formation TPS. The shale-oil AUs in the Paradox Basin were assessed to contain mean undiscovered, technologically recoverable resources of $0.47 \mathrm{BBO}, 398 \mathrm{BCFG}$, and 31 MMBNGL (Whidden and others, 2012). Supporting studies of the geologic models and the methodology used in the 2011 Paradox Basin assessment are in progress. Assessment results are available at the USGS Energy Resources Program website at http://energy.usgs.gov/OilGas/AssessmentsData/ NationalOilGasAssessment.aspx.

\section{Powder River Basin Province (Anna and others, 2006)}

The USGS completed an assessment of the undiscovered oil and gas potential of the Powder River Basin (PRB) in 2006, during which the Upper Cretaceous Mowry Shale and Niobrara Formation were identified as the primary hydrocarbon sources for Cretaceous conventional and unconventional reservoirs in the basin. The PRB, located in northeastern Wyoming and southeastern Montana, is one of many Rocky Mountain foreland basins that developed during the Laramide orogeny. The basin is asymmetric with the axis on the west side, where as much as $17,000 \mathrm{ft}$ of sedimentary rock overlies the Precambrian basement (Anna and others, 2009). Anna and others (2009) identified numerous structures observed at the surface that originated as faults, shear zones, or zones of weakness in the basement rocks during Precambrian time. These structural features were rejuvenated during the Laramide orogeny, and by periodic recurrent movement throughout the Phanerozoic. Most structures are oriented northwest-southeast and northeast-southwest, trends that probably influenced local and regional sedimentation patterns (Anna, 1986a, b). The Mowry Shale and the Niobrara Formation are self-contained petroleum systems. Anna and others (2009) reported TOC values for the Mowry Shale ranging from 2 to 4 weight percent near the middle of the formation, with Type II and Type III kerogen. The Niobrara Formation averages more than 3 weight percent TOC of Type II kerogen (Anna and others, 2009). Burial-history modeling by Anna and Cook (2008) indicated that hydrocarbon generation for both the Mowry Shale and the Niobrara Formation started at about 0.60 percent $\mathrm{R}_{\mathrm{o}}$ at depths of about 8,000 feet. At maximum depths, $R_{0}$ for the Mowry is about 1.2 to 1.3 percent and about 0.80 percent for the Niobrara. Anna and Cook (2008) defined overpressuring caused by hydrocarbon generation at an upper depth limit of $8,000 \mathrm{ft}$. Current and historical production data from unconventional fractured shale reservoirs with vertical wells were used to determine the EUR distribution for untested cells. Anna and Cook (2008) contended that horizontal drilling, state-of-the-art 
completion practices, and comprehensive fracture and fault analysis might increase the Mowry and Niobrara EUR distribution analogous to the Permian Spraberry Formation EURs in the Permian Basin, Texas. Mean estimates of undiscovered, technically recoverable, continuous-oil resources in the Powder River Basin are 0.42 BBO, 424 BCFG, and 25 MMBNGL (Anna and others, 2006). Supporting geologic studies and reports on the assessment method used in the Powder River Basin Province are available at the USGS Energy Resources Program website at http://energy.usgs.gov/ OilGas/AssessmentsData/NationalOilGasAssessment.aspx.

\section{Anadarko Basin Province (Higley and others, 2011)}

The Upper Devonian and Lower Mississippian Woodford Shale is an important oil and gas shale in Oklahoma, southern Kansas, and northeastern Texas. It contains mainly Type II kerogen with up to 25 weight percent TOC content (Comer, 1992; Johnson and Cardott, 1992; Roberts and Mitterer, 1992). In addition to its excellent hydrocarbon source rock potential, the marine Woodford Shale is quartz-rich, which may enhance its reservoir potential (Cardott, 2012). Higley and others (2011) defined the Woodford Shale-Oil AU and areas where production characteristics are relatively favorable (sweet spots) based primarily on: (1) extent and thickness of the formation, (2) filling of underlying Hunton Formation eroded channels, (3) historical and estimated ultimate recoverable production from existing wells, and (4) levels of thermal maturation based on 1D, 2D, and 3D petroleum system models and on $\mathrm{R}_{\mathrm{o}}$ maps and data. Higley's (2011) petroleum system model of the Anadarko Basin shows source rocks across Kansas and Colorado are mostly immature for oil generation; thermal maturity in the deeper parts in Oklahoma and Texas range from mature to overmature for hydrocarbon generation. Higley (2011) showed Woodford hydrous-pyrolysis transformation ratios of the onset of oil generation ( 0.1 percent) to completion of oil and the start of gas generation (99 percent) correlates to a range of about 0.65 to 1.2 percent $R_{0}$. Higley and others (2011) assessed a mean undiscovered, technically recoverable resource estimate for the Woodford Shale Oil AU of $0.39 \mathrm{BBO}, 2 \mathrm{TCFG}$, and 59 MMBNGL (Higley, 2011). Assessment results and geologic reports are available at the USGS website at http://energy.usgs.gov/OilGas/ AssessmentsData/NationalOilGasAssessment.aspx.

\section{Southwestern Wyoming (Finn and Johnson, 2005); Hanna, Laramie and Shirley Basins (Dyman and Condon, 2007); and Denver Basin Provinces (Higley and Cox, 2007)}

Finn and Johnson (2005) defined the Niobrara TPS as a self-sourced system that produces oil and natural gas from fractured carbonate rock reservoirs in the Upper Cretaceous Niobrara Formation and equivalent rocks in the Southwestern Wyoming Province. Dyman and Condon (2007) modeled two small Niobrara oil fields on the south flank of the Hanna Basin after continuous Niobrara oil fields in the Southwestern Wyoming Province, resulting in a continuous assessment unit that was defined and quantitatively assessed for Niobrara oil (Dyman and others, 2006). In the Denver Basin, oil was assessed for: (1) the Fractured Niobrara Limestone AU in the Upper Cretaceous Fractured Niobrara TPS, and (2) the Niobrara, combined with the underlying Codell Sandstone Member of the Carlile Shale, as part of the Cretaceous Composite TPS (Higley and others, 2003). The Niobrara and equivalents were deposited during a major Late Cretaceous marine transgressive cycle that created conditions favorable for the deposition of fine-grained marine carbonate rocks and the preservation of organic matter (Finn and Johnson, 2005). Black shales within the Niobrara Formation, some of which are rich in coccoliths and fecal pellets, are the major hydrocarbon source rocks; shaly beds that overlie the chalky or sandy reservoir intervals are seals (Longman and others, 1998). In the Southwestern Wyoming Province, Finn and Johnson (2005) found the thickness of the Niobrara ranges from 900 to $1,800 \mathrm{ft}$ and the lithology consists mainly of interbedded organic-rich shale, calcareous shale, and marl. Dyman and Condon (2007) describe the Niobrara as concretionary, containing ledge-forming coquina beds; the limestones and chalks in the Niobrara give off a strong petroliferous odor. Dyman and Condon (2007) support an interpretation of limited migration for Niobrara-derived oil and consider potential oil accumulations in the Niobrara to be continuous-type accumulations. The presence of oil, therefore, is based primarily on thermal maturity rather than on migration pathways (Dyman and Condon, 2007). Within the Western Interior Basin, Niobrara TOC ranges from 0.2 to 7.6 weight percent; the best values occur east of the Hanna, Laramie, and Shirley Basins Province in the area of Silo field in Laramie County, Wyoming, in the northern Denver Basin (Landon and others, 2001). Finn and Johnson (2005) found the majority of 28 Niobrara samples in the Southwestern Wyoming Province contain Type II, oil-prone kerogen with some mixing from Type III, gas-prone kerogen, especially in the western part of the province. Landon and others (2001) recognized a general increase in siliciclastic material in the Niobrara in the western part of the Cretaceous Western Interior Seaway, and source rock quality decreases. For the 2002 USGS assessment in the Southwestern Wyoming Province, the mean estimate of undiscovered, technically recoverable oil resource for the Niobrara continuous-oil assessment unit is $0.10 \mathrm{BBO}, 62.2 \mathrm{BCFG}$, and 3.7 MMBNGL (Kirschbaum, Finn, and others, 2002). In the Denver Basin, the mean estimate of undiscovered, technically recoverable oil resource for Niobrara continuous oil assessment units was $0.04 \mathrm{BBO}, 329.5 \mathrm{BCFG}$, and $33 \mathrm{MMBNGL}$ (Higley and others, 2003). The Niobrara Continuous Oil AU assessment in the Hanna, Laramie, Shirley Basins Province, 
Wyoming, resulted in an estimated mean of $0.04 \mathrm{BBO}$ and 19 BCFG (Dyman and others, 2006). Geologic studies of total petroleum systems and assessment units, as well as reports on the methodology used in assessing resources, for the Denver Basin; Southwestern Wyoming; and Hanna, Laramie, Shirley Basins Provinces of the Rocky Mountain region are available at the USGS Energy Resources Program Web site at http://energy.usgs.gov/OilGas/AssessmentsData/ NationalOilGasAssessment.aspx.

\section{Uinta-Piceance Basin Province (Dubiel, 2003)}

Dubiel (2003) reported the results of the 2002 geologic assessment of undiscovered oil and gas resources of the Green River TPS within the Uinta-Piceance Basin Province in northeastern Utah and northwestern Colorado. Dubiel (2003) described the Green River TPS as a prolific complex of entirely continental rocks that host gilsonite veins, oil shale, and tar sand all sourced from lacustrine rocks within the Paleocene and Eocene Green River Formation. The open-lacustrine facies averages about 6.0 weight percent total organic carbon, and locally has TOC contents as high as 60 weight percent. The kerogenous carbonate beds, referred to as oil shale, have hydrogen indices greater than 500 milligrams of hydrocarbon per gram of rock $(\mathrm{mg} \mathrm{HC} / \mathrm{g})$ TOC (see Dubiel, 2003). Oil shale in the Green River Formation-including the Piceance Basin of northwestern Colorado, the Uinta Basin of northeastern Utah, and the Greater Green River Basin of southwestern Wyoming - is the world's largest known deposit of kerogen-rich rocks (Dyni, 2006). The total potential resource within these deposits, regardless of grade, is estimated in the most recent U.S. Geological Survey resource in-place assessment to be 4.285 trillion barrels of oil (Johnson, Mercier, Brownfield, Pantea, and Self, 2010; Johnson, Mercier, Brownfield, and Self, 2010; Johnson and others, 2011; Birdwell and others, 2012). Dubiel (2003) described minor oil and gas production from an illitic oil-shale lacustrine facies with high TOC values in the Cow Ridge Member of the Green River Formation in the Piceance Basin. Most of the lacustrine rocks were not buried deeply enough in the Piceance Basin to achieve the necessary thermal maturity to have generated abundant hydrocarbons. In the Uinta Basin, however, Dubiel (2003) found that the greater depth of burial of the Green River Formation produced sufficient thermal maturity to generate abundant hydrocarbons. Dubiel (2003) defined the Deep Uinta Overpressured Continuous-Oil Assessment Unit primarily by the occurrence of known overpressured source and reservoir rocks in the Green River Formation in the deepest part of the Uinta Basin. The USGS estimated a mean undiscovered, technically recoverable continuous-oil resource of 0.04 BBO, 64 BCFG, and 4.5 MMBNGL (Kirschbaum, Anna, and others, 2002). Supporting geologic studies and the methodology used in the Uinta-Piceance Province assessment are available at the USGS Energy Resources Program website at http://energy.usgs.gov/OilGas/AssessmentsData/ NationalOilGasAssessment.aspx.

\section{Montana Thrust Belt Province (Schenk and others, 2002)}

The calcareous Cone Member of the Upper Cretaceous Marias River Shale in the Montana Disturbed Belt has good potential as a source rock for oil because of the relatively high hydrogen index values and above average organic carbon values (Clayton and others, 1983). Perry (1995) felt that an excellent chance existed for considerable oil production from the fractured Cone Member, particularly if wells are drilled to encounter the maximum number of fractures. The USGS defined and estimated the Marias River Shale Continuous-Oil AU to contain a mean of about $0.03 \mathrm{BBO}, 111 \mathrm{BCFG}$, and 5.6 MMBNGL (Schenk and others, 2002).

\section{Bighorn Basin Province (Finn and others, 2010)}

The Bighorn Basin developed primarily during the Laramide orogeny, a period of crustal instability that began during Late Cretaceous time and ended in early Eocene time (Gries, 1983; Love, 1988). Finn and others (2010) explain that many of the structures are the result of compressional deformation characterized by Precambrian basement-involved thrust faults (thick-skinned), wrench faults, and strongly folded and faulted anticlines and synclines. The basin covers approximately $10,400 \mathrm{mi}^{2}$ in north-central Wyoming and a small part of south-central Montana. The Mowry Shale is one of the principal source rocks in the Bighorn Basin Province with TOC content ranging from 0.08 to 3.6 weight percent and hydrogen index (HI) values ranging from 10 to 634 units (Finn and others, 2010). Finn and others (2010) suggest that the Mowry Fractured Shale Continuous-Oil Assessment Unit has potential to produce oil from fractured siliceous marine shale and interbedded siltstones and thin sandstones. The AU occupies approximately $1,000 \mathrm{mi}^{2}$ in the eastern and southern parts of the Bighorn Basin, and extends to depths of 12,000 ft (Finn and others, 2010). The closest analog for the Mowry Fractured Shale Continuous-Oil AU is the Mowry Continuous-Oil AU in the Powder River Basin (Anna and Cook, 2008); however, the Mowry source rock there has higher TOC content and Type II kerogen (Burtner and Warner, 1984). The mean estimate for undiscovered, technically recoverable oil resources in the Mowry Fractured Shale Continuous-Oil AU has potential for additions to reserves of $0.005 \mathrm{BBO}$ and $2 \mathrm{BCFG}$ (Kirschbaum and others, 2008). Supporting geologic studies of total petroleum systems and assessment units, and reports on the methodology used in the Bighorn Basin Province assessment, are available at the USGS Energy Resources Program website at http://energy.usgs.gov/OilGas/AssessmentsData/ NationalOilGasAssessment.aspx. 


\section{Digital Maps and Data}

This fourth digital map product in the series of USGS unconventional oil and gas resources maps represents the results of the 2000-series of USGS geologic assessments of the undiscovered continuous-oil resources in the U.S. For current and future reference, the USGS publishes the assessment data as a Geographic Information System (GIS) map and data package. The map is also available as a static Portable Document Format (.pdf) file. To access the hardcopy .pdf map, click on the map graphic shown in figure 1. Adobe Acrobat Reader software can be used to view the .pdf map and is available for download free-of-charge at http://get.adobe.com/reader/. The hardcopy .pdf map is designed to be printed on a $46 \times 33$ inch map sheet.

The GIS map and data package is contained on CD-ROM or can be downloaded at the USGS website http://pubs.usgs.gov/ dds/dds-069/dds-069-jj/ or http://dx.doi.org/10.3133/ds69jj.

The ArcMap document contains an .mxd extension on the filename, is the main component of the GIS data package, and is used to analyze geospatial data, symbolize features, and create maps. Access to the .mxd file uses Esri's ArcGIS 10 or newer versions of the desktop software (Esri, 2000). Using the published .mxd and the ArcGIS Publisher extension (Esri, 2008a) in ArcMap, a special file called a published map file was created. Published map files contain a .pmf extension and can be accessed using any ArcGIS (Esri, 2000) desktop product, including the free-of-charge ArcReader (Esri, 2008b) application. ArcMap and ArcReader offer different ways to view a map in which one can perform map-based tasks. ArcReader provides basic tools for map viewing, printing and querying of geospatial data. More advanced geospatial processing requires the ArcGIS suite of geospatial processing programs, including ArcMap.

There are two ArcMap projects contained in this report: (1) ContinuousOilMap2014.mxd, and (2) ContinuousOilMap2014simplified.mxd. ContinuousOilMap2014.mxd is a complex ArcGIS project used to build, design, and export the .pdf map. Multiple data frames were used to enlarge and enhance each province area; upon initial launch, this file tends to be much slower than subsequent map starts. The ContinuousOilMap2014simplified.mxd is designed for the novice GIS user to easily navigate and utilize the data.

The digital map layout of both the .mxd and the .pmf, contains a map window with a series of layers in the table of contents frame on the left side of the navigation screen. Within the table of contents, select the box to the left of each layer or group of layers to display the features in map view. Click the "+" sign to the left of each layer, group, or data frame to display the symbology or the list of layers within that group or data frame. To deselect the entire group, ctrl-click the check box to the left of any one of the AU names. Ctrl-click again to toggle the check boxes on for the entire group.

By default, the map is displayed in Layout View, and the Contiguous U.S. (lower 48) is the active data frame. Layout View is designed to work with the map layout and graphic elements, such as titles, north arrows, and scale bars, along with the data frame, all of which are arranged on a page. Data View is designed for exploring, displaying, and querying the data sets presented on your map, which is displayed in real-world coordinates (Esri, 2011). Navigation between Layout View and Data View is available from the View drop-down menu.

Labels and annotation for the AUs are included as separate layers that can be toggled on and off, as deemed appropriate for a particular map display. In the simplified .mxd, the "Continuous-Oil AU Annotation" layer, when visible, shows all continuous-oil AU names. Users may zoom into a specific area of interest, in which case, individual province labels available within each province group can be toggled on and the AU annotation layer can be toggled off (made invisible).

ArcMap projects (.mxd) and published map files (.pmf) can be enhanced by including auxiliary base map layers, many of which are available as ArcGIS services (for example, shaded relief, World imagery; Esri, 2010). Another important base layer, geologic units from the Geologic Map of North America (Reed and others, 2005; Garrity and Soller, 2009), is included for additional geologic context. Because many of these base layers are very large files, having them toggled on (visible in the map view) can adversely affect performance. Several base layers are visible upon opening the map project. Toggling these layers off can increase refresh and display performance while navigating the interactive map. Once an appropriate map graphic has been created, or area of interest has been isolated, the addition of one or more of the base layers can enhance the final map product or view.

All geospatial data are stored in file geodatabase (Esri, 2012; ContinuousOil2014.gdb and BaseLayers.gdb) and shapefile format in a World Geodetic System (WGS) 1984 projection, which is a standard projection for distributing geospatial data.

The polygons in ContinuousOil2014.gdb represent continuous-oil assessment units (AUs) that have been defined and assessed by the USGS. An important aspect of this map product is that it does not require extensive GIS expertise or highly specialized equipment.

The Metadata folder contains continuous-oil data documentation in XML, html, and text format. The base map layers have metadata incorporated from the published sources. Reference or base map layers from "The National Atlas of the United States of America" (U.S. Department of the Interior, 2008) include: state and county boundaries, streams, water bodies, and urban areas in the U.S. For the ArcGIS.com web services (formerly ArcGIS Online; Esri, 2010), data descriptions, sources, and credits are stored as layer properties. 


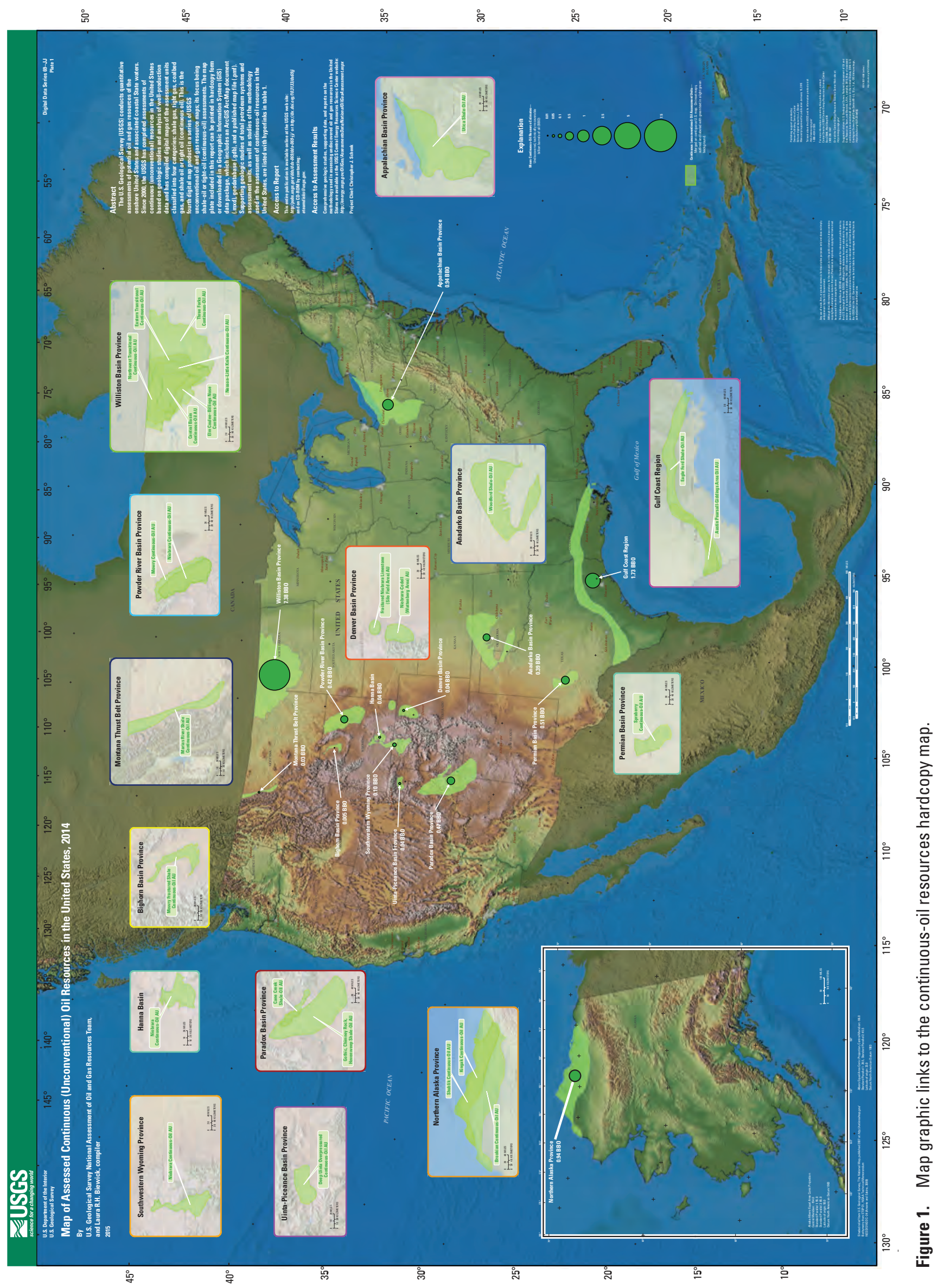




\section{Summary}

The USGS map of the principal continuous-oil resources in the U.S. displays the occurrence of this important resource in many regions of the country. Although the complexities of the geologic parameters that influence the success of a continuous-oil play in a given basin or setting are generally understood, estimates of the continuous-oil resource, especially the portion that is technically recoverable, are likely to change over time as our geologic understanding of the resource characteristics increases and with further advances in technology and recovery methods. New information can readily be added to this digital baseline, and the ability to visualize, display, and analyze geospatial data can enhance and (or) increase the understanding of continuous-oil resources and assessments in the future.

\section{Acknowledgments}

This report is a compilation of work by many USGS geologists who presented the geologic evidence critical to defining and assessing the continuous-oil resource volumes across the U.S. The manuscript was improved by reviews from Christopher J. Schenk, Thomas Finn, and Dave Ferderer, and thanks are extended to them for their thoughtful evaluations and suggested revisions.

\section{References Cited}

Amante, Christopher, and Eakins, B.W., 2009, ETOPO1 1 Arc-minute global relief model-Procedures, data sources and analysis: National Oceanic and Atmospheric Administration (NOAA) Technical Memorandum NESDIS NGDC-24, 19 p. [Also available at http://www.ngdc.noaa. gov/mgg/global/relief/ETOPO1/.]

Anna, L.O., 1986a, Geologic framework of the ground water system in Jurassic and Cretaceous rocks on the Northern Great Plains, in parts of Montana, North Dakota, South Dakota, and Wyoming: U.S. Geological Survey Professional Paper 1402-B, 36 p. [Also available at http://pubs.er.usgs. gov/publication/pp1402B.]

Anna, L.O., 1986b, Structural influence on Cretaceous sedimentation, northern Great Plains-Part II, northern Rocky Mountains, in Peterson, J.A., ed., Paleotectonics and sedimentation in the Rocky Mountain region: Tulsa, American Association of Petroleum Geologists Memoir 41, p. 173-192, accessed on December 20, 2013, at http://archives.datapages.com/data/specpubs/structul/ data/a155/a155/0001/0150/0173.htm.
Anna, L.O., Charpentier, R.R., Cook, T.A., Klett, T.R., Pollastro, R.M., and Schenk, C.J., 2006, Assessment of undiscovered oil and gas resources of the Powder River Basin Province of Wyoming and Montana-2006 update: U.S. Geological Survey Fact Sheet 2006-3135, 2 p. [Also available at http://pubs.usgs.gov/fs/2006/3135/.]

Anna, L.O., and Cook, T.A., 2008, Assessment of the Mowry Shale and Niobrara Formation as continuous hydrocarbon systems, Powder River Basin, Montana and Wyoming, American Association of Petroleum Geologists Rocky Mountain Section Conference, July 9, 2008, Denver, Colo.: U.S. Geological Survey Open-File Report 2008-1367, 1 sheet. [Also available at http://pubs.usgs.gov/ of/2008/1367/.]

Anna, L.O., Klett, T.R., and Le, P.A., 2009, Geologic assessment of undiscovered oil and gas in the Powder River Basin Province, Wyoming and Montana, chap. 1, of Anna, L.O., Klett, T.R., and Le, P.A., 2009, Total petroleum systems and geologic assessment of oil and gas resources in the Powder River Basin Province, Wyoming and Montana: U.S. Geological Survey Digital Data Series DDS-69-U, 102 p. [Also available at: http://pubs.usgs.gov/dds/dds-069/ dds-069-u/PDF/Chapter1.pdf.]

Barbeau, D.L., 2003, A flexural model for the Paradox Basin-Implications for the tectonics of the Ancestral Rocky Mountains: Basin Research, v. 15, p. 97-115, accessed December 19, 2013, at http://onlinelibrary.wiley. com/doi/10.1046/j.1365-2117.2003.00194.x/full.

Birdwell, J.E., Mercier, T.J., Johnson, R.C., and Brownfield, M.E., 2013, In-place oil shale resources examined by grade in the major basins of the Green River Formation, Colorado, Utah, and Wyoming: U.S. Geological Survey Fact Sheet 2012-3145, 4 p. [Also available at http://pubs.usgs.gov/ $\left.f_{s} / 2012 / 3145 /.\right]$

Bottjer, R.J., Sterling, Robert, Grau, Anne, Dea, Peter, 2011, Stratigraphic relationships and reservoir quality at the Three Forks-Bakken unconformity in the North Dakota part of Williston Basin, North Dakota, in Robinson, J.W., LeFever, J.A., and Gaswirth, S.B., eds., 2011, The Bakken-Three Forks Petroleum System in the Williston Basin: The Rocky Mountain Association of Geologists, ISBN 0-933979-32-0.

Burtner, R.L., and Warner, M.A., 1984, Hydrocarbon generation in Lower Cretaceous Mowry and Skull Creek Shales of the northern Rocky Mountain area, in Woodward, J.F., Meissner, F.F., and Clayton, J.L., eds., Hydrocarbon source rocks of the greater Rocky Mountain Region: Rocky Mountain Association of Geologists Guidebook, p. 449-467. 
Cardott, B.J., 2012, Thermal maturity of Woodford Shale gas and oil plays, Oklahoma, USA: International Journal of Coal Geology, v. 103, p. 109-119, accessed December 11, 2013, at http://www. sciencedirect.com/science/article/pii/S0166516212001632.

Clayton, J.L., Mudge, M.R., Lubeck, Sr., C., and Daws, T.A., 1983, Hydrocarbon source rock evaluation of the disturbed belt, northwestern Montana, in Powers, R.B., ed., Geologic studies of the Cordilleran thrust belt-1982: Rocky Mountain Association of Geologists, v. 2, p. 817-830.

Comer, J.B., 1992, Organic geochemistry and paleogeography of Upper Devonian formations in Oklahoma and Western Arkansas, in Johnson, K.S., Cardott, B.J., eds., Source rocks in the Southern Midcontinent, 1990 Symposium: Oklahoma Geological Survey Circular, 93, p. 70-93, accessed December 11, 2013, at http://www.ogs.ou.edu/pubsscanned/ Circulars/Circular93.pdf.

Dubiel, R. F., 2003, Geology, depositional models, and oil and gas assessment of the Green River Total Petroleum System, Uinta-Piceance Province, eastern Utah, and western Colorado, chap. 5 of U.S. Geological Survey Uinta-Piceance Assessment Team, compilers, Petroleum systems and geologic assessment of oil and gas the Uinta-Piceance Province, Utah and Colorado: U.S. Geological Survey Digital Data Series 69-B, 45 p. [Also available at http://pubs.usgs. gov/dds/dds-069/dds-069-b/REPORTS/Chapter_5.pdf.]

Dubiel, R.F., Huntoon, J.E., Condon, S.M., Stanesco, J.D., 1996, Permian deposystems, paleogeography, and paleoclimate of the Paradox Basin and vicinity, in Longman, M.W., and Sonnenfeld, M.D., eds., Paleozoic Systems of the Rocky Mountain Region: Rocky Mountain Section-SEPM (Society for Sedimentary Geology), p. 427-444, accessed December 19, 2013, at http://archives.datapages.com/data/ rocky_sepm/data/034/034001/427_rocky_mount340427.htm.

Dubiel, R.F., Pitman, J.K., Pearson, O.N., Pearson, Krystal, Kinney, S.A., Lewan, M.D., Burke, Lauri, Biewick, L.R.H., Charpentier, R.R., Cook, T.A., Klett, T.R., Pollastro, R.M., and Schenk, C.J., 2012, Assessment of undiscovered oil and gas resources in conventional and continuous petroleum systems in the Upper Cretaceous Eagle Ford Group, U.S. Gulf Coast region, 2011: U.S. Geological Survey Fact Sheet 2012-3003, 2 p. [Also available at http://pubs.usgs. gov/fs/2012/3003/.]

Dubiel, R.F., Warwick, P.D., Swanson, Sharon, Burke, Lauri, Biewick, L.R.H., Charpentier, R.R., Coleman, J.L., Cook, T.A., Dennen, Kris, Doolan, Colin, Enomoto, Catherine, Hackley, P.C., Karlsen, A.W., Klett, T.R., Kinney, S.A., Lewan, M.D., Merrill, Matt, Pearson, Krystal, Pearson, O.N., Pitman, J.K., Pollastro, R.M., Rowan, E.L., Schenk, C.J., and Valentine, Brett, 2011, Assessment of undiscovered oil and gas resources in Jurassic and Cretaceous strata of the Gulf Coast, 2010: U.S. Geological Survey Fact Sheet 2011-3020, 4 p. [Also available at http://pubs.usgs.gov/ $\left.f_{s} / 2011 / 3020 /.\right]$
Dyman, T.S., and Condon, S.M., 2007, 2005 Geologic assessment of undiscovered oil and gas resources, Hanna, Laramie, and Shirley Basins Province, Wyoming and Colorado, chap. 2 of U.S. Geological Survey Hanna, Laramie, and Shirley Basins Province Assessment Team, ed., Petroleum Systems and Geologic Assessment of Undiscovered Oil and Gas, Hanna, Laramie, and Shirley Basins Province, Wyoming: U.S. Geological Survey Digital Data Series 69-K, 68 p. [Also available at http://pubs.usgs.gov/dds/dds-069/ dds-069-k/REPORTS/69_K_CH_2.pdf.]

Dyman, T.S., Condon, S.M., Ahlbrandt, T.S., Charpentier, R.R.., Cook, T.A., Klett, T.R., Lewan, M.D., Lillis, P.G., Pawlewicz, M.J., Pollastro, R.M., and Schenk, C.J., 2006, 2005 Assessment of undiscovered oil and gas resources in the Hanna, Laramie, and Shirley Basins Province, Wyoming: U.S. Geological Survey Fact Sheet 2005-3125, 4 p. [Also available at http://pubs.usgs.gov/fs/2005/3125/.]

Dyni, J.R., 2006. Geology and resources of some world oil-shale deposits: U.S. Geological Survey Scientific Investigations Report 2005-5294, 42 p. [Also available at http://pubs.usgs.gov/sir/2005/5294/pdf/sir5294_508.pdf.]

Esri, 2000, ArcGIS: Redlands, Calif., Environmental Systems Research Institute, Inc., accessed January 27, 2012, at http://www.esri.com/software/arcgis/index.html.

Esri, 2008a, ArcPublisher: Redlands, Calif., Environmental Systems Research Institute, Inc., accessed on January 27, 2012, at http://www.esri.com/software/arcgis/ extensions/publisher/index.html and http://www.esri.com/ software/arcgis/extensions/publisher/publishing.html.

Esri, 2008b, ArcReader: Redlands, Calif., Environmental Systems Research Institute, Inc., accessed January 27, 2012, at http://www.esri.com/software/arcgis/arcreader/download.html.

Esri, 2010, ArcGIS online: Redlands, Calif., Environmental Systems Research Institute, Inc., accessed January 27, 2012, at http://www.esri.com/software/arcgis/arcgisonline/index.html.

Esri, 2011, Displaying maps in data view and layout view, ArcGIS Desktop 10.0 Help: Redlands, Calif., Environmental Systems Research Institute, Inc.

Esri, 2012, Geodatabase: Redlands, Calif., Environmental Systems Research Institute, Inc., accessed January 27, 2012, at http://www.esri.com/software/arcgis/geodatabase/index.html.

Finn, T.M., Kirschbaum, M.A., Roberts, S.B., Condon, S.M., Roberts, L.N.R., and Johnson, R.C., 2010, CretaceousTertiary Composite Total Petroleum System (503402), Bighorn Basin, Wyoming and Montana, chap. 3, of USGS Bighorn Basin Assessment Team, ed., Petroleum systems and geologic assessment of oil and gas in the Bighorn Basin Province, Wyoming and Montana: U.S. Geological Survey Digital Data Series 69-V, 163 p. [Also available at http://pubs.usgs. gov/dds/dds-069/dds-069-v/REPORTS/69_V_CH_3.pdf.] 
Finn, T.M. and Johnson, R.C., 2005, Niobrara Total Petroleum System in the Southwestern Wyoming Province, chap. 6 of USGS Southwestern Wyoming Province Assessment Team, ed., Petroleum systems and geologic assessment of oil and gas in the Southwestern Wyoming Province, Wyoming, Colorado, and Utah: U.S. Geological Survey Digital Data Series 69-D, 31 p. [Also available at: http://pubs.usgs.gov/ $\left.d d s / d d s-069 / d d s-069-d / R E P O R T S / 69 \_D \_C H \_6 . p d f.\right]$

Garrity, C.P., and Soller, D.R., 2009, Database of the geologic map of North America-Adapted from the map by Reed, J.C., Jr. and others (2005): U.S. Geological Survey Data Series 424. [Also available at $h t t p: / / p u b s . u s g s . g o v / d s / 424 /$.

Gaswirth, S.B., Marra, K.R., Cook, T.A, Charpentier, R.R., Gautier, D.L., Higley, D.K., Klett, T.R., Lewan, M.D., Lillis, P.G., Schenk, C.J., Tennyson, M.E., and Whidden, K.J., 2013, Assessment of undiscovered oil resources in the Bakken and Three Forks Formations, Williston Basin Province, Montana, North Dakota, and South Dakota, 2013: U.S. Geological Survey Fact Sheet 2013-3013, 4 p. [Also available at $h t t p: / / p u b s . u s g s . g o v / f s / 2013 / 3013 /$.

Gries, R.R., 1983, North-south compression of Rocky Mountain foreland structures, in Lowell, J.D., and Gries, R.R., eds., Rocky Mountain foreland basins and uplifts: Rocky Mountain Association of Geologists, p. 9-32.

Handford, C.R., 1981, Sedimentology and genetic stratigraphy of Dean and Spraberry Formations (Permian), Midland Basin, Texas: American Association of Petroleum Geologists Bulletin, v. 65, no. 9, p. 1602-1616, accessed December 18, 2013, at http://archives.datapages.com/data/ bulletns/1980-81/data/pg/0065/0009/1600/1602.htm?q=\%2 BtextStrip\%3Ashelf+textStrip\%3Acarbonate+textStrip\%3A sedimentation+textStrip\%3Acontrolled + textStrip\%3Asalinit $y+$ textStrip\%3Aparadox+textStrip\%3Abasin+textStrip $\% 3 \mathrm{~A}$ southeast+textStrip\%3Autah.

Higley, D.K., compiler, 2007, Petroleum systems and assessment of undiscovered oil and gas in the Denver Basin Province, Colorado, Kansas, Nebraska, South Dakota, and Wyoming-USGS Province 39: U.S. Geological Survey Digital Data Series 69-P. [Also available at http://pubs.usgs.gov/dds/dds-069/dds-069-p/.]

Higley, D.K., 2011, Undiscovered petroleum resources for the Woodford Shale and Thirteen Finger Limestone-Atoka Shale assessment units, Anadarko Basin: U.S. Geological Survey Open-File Report 2011-1242, 3 sheets. [Also available at http://pubs.usgs.gov/of/2011/1242/.]

Higley, D.K., Charpentier, R.R., Cook, T.A., Klett, T.R., Pollastro, R.M., Schmoker, J.W., and Schenk, C.J., 2003, 2002 USGS Assessment of oil and gas resource potential of the Denver Basin Province of Colorado, Kansas, Nebraska, South Dakota, and Wyoming: U.S. Geological Survey Fact Sheet 002-03, 3 p. [Also available at: http://pubs.usgs.gov/ $\left.f_{s} / f_{s}-002-03 /.\right]$
Higley, D.K., and Cox, D.O., 2007, Oil and gas exploration and development along the Front Range in the Denver Basin of Colorado, Nebraska, and Wyoming, chap. 2 of Higley, D. K., compiler, ed., Petroleum systems and assessment of undiscovered oil and gas in the Denver Basin Province, Colorado, Kansas, Nebraska, South Dakota, and Wyoming-USGS Province 39: U.S. Geological Survey Digital Data Series 69-P, 45 p. [Also available at http://pubs.usgs.gov/dds/dds-069/dds-069-p/ REPORTS/69_P_CH_2.pdf.]

Higley, D.K., Gaswirth, S.B., Abbott, M.M., Charpentier, R.R., Cook, T.A., Ellis, G.S., Gianoutsos, N.J., Hatch, J.R., Klett, T.R., Nelson, Philip, Pawlewicz, M.J., Pearson, O.N., Pollastro, R.M., and Schenk, C.J., 2011, Assessment of undiscovered oil and gas resources of the Anadarko Basin Province of Oklahoma, Kansas, Texas, and Colorado, 2010: U.S. Geological Survey Fact Sheet 2011-3003, 2 p. [Also available at $h t t p: / / p u b s . u s g s . g o v / f s / 2011 / 3003 /$.

Houseknecht, D.W., Rouse, W.A., Garrity, C.P., Whidden, K.J., Dumoulin, J.A., Schenk, C.J., Charpentier, R.R., Cook, T.A., Gaswirth, S.B., Kirschbaum, M.A., and Pollastro, R.M., 2012, Assessment of potential oil and gas resources in source rocks of the Alaska North Slope, 2012: U.S. Geological Survey Fact Sheet 2012-3013, 2 p. [Also available at $h t t p: / / p u b s . u s g s . g o v / f s / 2012 / 3013$.

Johnson, K.S., and Cardott, B.J., 1992, Geologic framework and hydrocarbon source rocks of Oklahoma, in Johnson, K.S., Cardott, B.J., eds., Source rocks in the Southern Midcontinent, 1990 Symposium: Oklahoma Geological Survey Circular 93, p. 21-37, accessed December 11, 2013, at http://www.ogs.ou.edu/ pubsscanned/Circulars/Circular93.pdf.

Johnson, M.S., 2001, Discovery of oil in the Williston BasinStory of the \#1 Clarence Iverson well: The Mountain Geologist, v. 38, no. 4, p. 165-180. [Also available at $h t t p: / /$ archives.datapages.com/data/rmag/mg/2001/johnson.htm.]

Johnson, R.C., Mercier, T.J., Brownfield, M.E., Pantea, M.P., and Self, J.G., 2010, An assessment of in-place oil shale resources in the Green River Formation, Piceance Basin, Colorado, chap. 1 of Oil shale and nahcolite resources of the Piceance Basin, Colorado: U.S. Geological Survey Digital Data Series 69-Y, 187 p. [Also available at http://pubs.usgs. gov/dds/dds-069/dds-069-y/REPORTS/69_Y_CH_1.pdf.]

Johnson, R.C., Mercier, T.J., Brownfield, M.E., and Self, J.G., 2010, Assessment of in-place oil shale resources in the Eocene Green River Formation, Uinta Basin, Utah and Colorado, chap. 1 of Oil shale resources of the Uinta Basin, Utah and Colorado: U.S. Geological Survey Digital Data Series 69-BB, 153 p. [Also available at http://pubs.usgs. gov/dds/dds-069/dds-069-bb/REPORTS/69_BB_CH_1.pdf.] 
Johnson, R.C., Mercier, T.J., Ryder, R.T., Brownfield, M.E., and Self, J.G., 2011, Assessment of in-place oil shale resources in the Eocene Green River Formation, Greater Green River Basin, Wyoming, Colorado, and Utah, chap. 1 of Oil shale resources of the Eocene Green River Formation, Greater Green River Basin, Wyoming, Colorado, and Utah: U.S. Geological Survey Digital Data Series 69-DD, 63 p. [Also available at http://pubs.usgs.gov/dds/dds-069/ dds-069-dd/REPORTS/69_DD_CH_1.pdf.]

Kirschbaum, M.A., Anna, L.O., Collett, T.S., Dubiel, R.F., Finn, T.M., Hettinger, R.D., Henry, M.E., Johnson, E.A., Johnson, R.C., Lillis, P.G., Nelson, P.H., Nuccio, V.F., Rice, C.A., Roberts, L.N.R., and Roberts, S.B., 2002, Assessment of undiscovered oil and gas resources of the Uinta-Piceance Province of Colorado and Utah, 2002: U.S. Geological Survey Fact Sheet 026-02, 2 p. [Superseded Feb. 2003 by USGS Fact Sheet FS-157-02, available at http://pubs.usgs.gov/fs/fs-157-02/FS-157-02.pdf.]

Kirschbaum, M.A., Condon, S.M., Finn, T.M., Johnson, R.C., Lillis, P.G., Nelson, P.H., Roberts, L.N.H., Roberts, S.B., Charpentier, R.R., Cook, T.A., Klett, T.R., Pollastro, R.M., and Schenk, C.J., 2008, Assessment of Undiscovered Oil and Gas Resources of the Bighorn Basin Province, Wyoming and Montana, 2008: U.S. Geological Survey Fact Sheet 2008-3050, 2 p. [Also available at http://pubs.usgs. gov/fs/2008/3050/.]

Kirschbaum, M.A., Finn, T.M., Hettinger, R.D., Johnson, E.A., Johnson, R.C., Kibler, J., Lillis, P.G., Nelson, P.H., Roberts, L.N.R., Roberts, S.B., Charpentier, R.R., Cook, T.A., Crovelli, R.A., Klett, T.R., Pollastro, R.M., and Schenk, C.J., 2002, Assessment of undiscovered oil and gas resources of the Southwestern Wyoming Province, 2002: U.S. Geological Survey Fact Sheet 145-02, 2 p. [Also available at $h t t p: / / p u b s . u s g s . g o v / f s / f s-145-02 /$.

Kirschbaum, M.A., Schenk, C.J., Cook, T.A., Ryder, R.T., Charpentier, R.R., Klett, T.R., Gaswirth, S.B., Tennyson, M.E., and Whidden, K.J., 2012, Assessment of undiscovered oil and gas resources of the Ordovician Utica Shale of the Appalachian Basin Province, 2012: U.S. Geological Survey Fact Sheet 2012-3116, 6 p. [Also available at $h t t p: / / p u b s . u s g s . g o v / f s / 2012 / 3116 /$. .]

Klett, T.R., Schmoker, J.W., Charpentier, R.R., Ahlbrandt, T.S., and Ulmishek, G.F., 2000, Glossary, chap. GL of U.S. Geological Survey World Petroleum Assessment 2000 - Description and results: U.S. Geological Survey Digital Data Series 60. [Also available at http://pubs.usgs. gov/dds/dds-060/.]
Kluth, C.F., and DuChene, H.R., 2009, Late Pennsylvanian and Early Permian structural geology and tectonic history of the Paradox Basin and Uncompahgre Uplift, Colorado and Utah, in Houston, W.S., Wray, L.L., and Moreland, P.G., eds., The Paradox Basin revisited-New developments in petroleum systems and basin analysis: Rocky Mountain Association of Geologists Special Publication-The Paradox Basin, p. 178-197.

Landon, S.M., Longman, M.W., and Luneau, B.A., 2001, Hydrocarbon source rock potential of the Upper Cretaceous Niobrara Formation, Western Interior Seaway of the Rocky Mountain region: The Mountain Geologist, v. 38, no. 1, p. 1-18.

Lillis, P.G., 2013, Review of oil families and their petroleum systems of the Williston Basin: The Mountain Geologist, v. 50 , no. 1, p. $5-31$.

Longman, M.W., Luneau, B.A., and Landon, S.M., 1998, Nature and distribution of Niobrara lithologies in the Cretaceous Western Interior Seaway of the Rocky Mountain Region: The Mountain Geologist, v. 35, no. 4, p. 137-170.

Love, J.D., 1988, Geology of the Bighorn Basin, northern Wyoming and southern Montana, Basins of the Rocky Mountain Region, chap. 8 of Sloss, L.L., ed., Sedimentary Cover-North American Craton, U.S.: The Geology of North America: Geological Society of America, v. D-2, p. 201-204.

Milici, R.C., Ryder, R.T., Swezey, C.S., Charpentier, R.R., Cook, T.A., Crovelli, R.A., Klett, T.R., Pollastro, R.M., and Schenk, C.J., 2003, Assessment of undiscovered oil and gas resources of the Appalachian Basin Province, 2002: U.S. Geological Survey Fact Sheet 009-03, 4 p. [Also available at $h t t p: / / p u b s . u s g s . g o v / f s / f s-009-03 /$.

Nelson, P.H., and Gianoutsos, N.J., 2011, Evolution of overpressured and underpressured oil and gas reservoirs, Anadarko Basin of Oklahoma, Texas, and Kansas: U.S. Geological Survey Open-File Report 2011-1245, 3 sheets. [Also available at http://pubs.usgs.gov/of/2011/1245.]

Nelson, P.H., and Santus, S.L., 2011, Gas, water, and oil production from Wattenberg field in the Denver Basin, Colorado: U.S. Geological Survey Open-File Report 2011-1175, 23 p., 2 pls. [Also available at http://pubs.usgs.gov/of/2011/1175/.]

Nordquist, J.W., 1953, Mississippian stratigraphy of northern Montana, in Parker, J.M., ed., Little Rocky MountainsMontana and Southwestern Saskatchewan, Fourth Annual Field Conference: Billings Geological Society Guidebook, Billings, Montana, p. 68-82. 
Nuccio, V.F., and Condon, S.M., 1996, Burial and thermal history of the Paradox Basin, Utah and Colorado, and petroleum potential of the Middle Pennsylvanian Paradox Formation: U.S. Geological Survey Bulletin 2000-O, 47 p. [Also available at $h t t p: / / p u b s . u s g s . g o v / b u l / b 2000 o /$ b2000o.html.]

Pawlewicz, M.J., and Finn, T.M., 2012, Vitrinite reflectance data for Cretaceous marine shales and coals in the Bighorn Basin, north-central Wyoming and south-central Montana: U.S. Geological Survey Open-File Report 2012-1254, 11 p. [Also available at http://pubs.usgs.gov/of/2012/1254/.]

Pearson, Krystal, Dubiel, R.F., Pearson, O.N., and Pitman, J.K., 2011, Assessment of undiscovered oil and gas resources of the Upper Cretaceous Austin Chalk and Tokio and Eutaw Formations, Gulf Coast, 2010: U.S. Geological Survey Fact Sheet 2011-3046, 2 p. [Also available at http://pubs.usgs. gov/fs/2011/3046/.]

Pearson, Krystal, 2012, Geologic models and evaluation of undiscovered conventional and continuous oil and gas resources-Upper Cretaceous Austin Chalk, U.S. Gulf Coast: U.S. Geological Survey Scientific Investigations Report 2012-5159, 26 p., http://pubs.usgs.gov/ sir/2012/5159/.

Perry, W.J., Jr., 1995, Montana Thrust Belt Province (027), in Gautier, D.L., Dolton, G.L., Takahashi, K.I., and Varnes, K.L., eds., 1995 National assessment of United States oil and gas resources - Results, methodology, and supporting data: U.S. Geological Survey Digital Data Series 30, release 2. [Also available on CD-ROM and at http://certmapper.cr.usgs.gov/ data/noga95/prov27/text/prov27.pdf.]

Pollastro, R.M., Cook, T.A., Roberts, L.N.R., Schenk, C.J., Lewan, M.D., Anna, L.O., Gaswirth, S.B., Lillis, P.G., Klett, T.R., and Charpentier, R.R., 2008, Assessment of undiscovered oil resources in the Devonian-Mississippian Bakken Formation, Williston Basin Province, Montana and North Dakota, 2008: U.S. Geological Survey Fact Sheet 2008-3021, 2 p. [Also available at http://pubs.usgs.gov/ $\left.f_{S} / 2008 / 3021 /.\right]$

Reed, J.C., Jr., Wheeler, J.O., and Tucholke, B.E., 2005, Geologic map of North America-Perspectives and explanation: Boulder, Colo., Geological Society of America, Decade of North American Geology, 3 sheets (74×39), scale 1:5,000,000, 28 p., accessed June 5, 2013, at $h t t p: / / w w w . g e o s o c i e t y . o r g / n e w s / p r / 05-04 . h t m$.

Repetski, J.E., Ryder, R.T., Weary, D.J., Harris, A.G., and Trippi, M.H., 2008, Thermal maturity patterns (CAI and \% $\mathrm{R}_{\mathrm{o}}$ ) in Upper Ordovician and Devonian rocks of the Appalachian Basin-A major revision of USGS Map I-917-E using new subsurface collections: U.S. Geological Survey Scientific Investigations Map 3006, 41 p., 3 sheets. [Also available at http://pubs.usgs.gov/sim/3006/.]
Roberts, C.T. and Mitterer, R.M., 1992, Laminated black shale-bedded chert cyclicity in the Woodford Formation, southern Oklahoma, in Johnson, K.S., Cardott, B.J., eds., Source rocks in the Southern Midcontinent, 1990 Symposium, February 6-7, Proceedings: Norman, Okla., Oklahoma Geological Survey Circular, 93, p. 330-336, accessed December 11, 2013 at http://www.ogs.ou.edu/pubsscanned/ Circulars/Circular93.pdf.

Robinson, J.W., LeFever, J.A., and Gaswirth, S.B., eds., 2011, The Bakken-Three Forks Petroleum System in the Williston Basin: Denver, Colo., The Rocky Mountain Association of Geologists, ISBN 0-933979-32-0.

Robinson, Keith, 1988, Petroleum geology and hydrocarbon plays of the Permian Basin Petroleum Province, west Texas and southeast New Mexico: U.S. Geological Survey OpenFile Report 88-450Z, 53 p. [Also available at $h t t p: / / p u b s$. er.usgs.gov/publication/ofr88450Z.]

Ryder, R.T., 2008, Assessment of Appalachian Basin oil and gas resources-Utica-Lower Paleozoic Total Petroleum System: U.S. Geological Survey Open-File Report 2008-1287, 29 p. [Also available at http://pubs.usgs.gov/of/2008/1287/.]

Schenk, C.J., Charpentier, R.R, Cook, T.A., Dyman, T.S., French, C.D., Henry, M.E., Klett, T.R., Perry, W.J., Pollastro, R.M., and Potter, C.J., 2002, Assessment of undiscovered oil and gas resources of the Montana Thrust Belt Province, 2002: U.S. Geological Survey Fact Sheet 148-02, 2 p. [Also available at $\left.h t t p: / / p u b s . u s g s . g o v / f_{s} / f_{s}-148-02 /.\right]$

Schenk, C.J., Pollastro, R.M., Cook, T.A., Pawlewicz, M.J., Klett, T.R., Charpentier, R.R., and Cook, H.E., 2008, Assessment of undiscovered oil and gas resources of the Permian Basin Province of west Texas and southeast New Mexico, 2007, U.S. Geological Survey Fact Sheet 2007-3115, 4 p. [Also available at http://pubs.usgs.gov/ $f_{s} / 2007 / 3115 /$.]

Schenk, Oliver, Bird, K.J., Peters, K.E., Magoon, L.B., 2011, Development of petroleum systems in Northern Alaska-Timing of petroleum system events controls presence of accumulations, adapted from extended abstract presented at GEO-India, Greater Noida, New Delhi, India, January 12-14, 2011: American Association of Petroleum Geologists, Search and Discovery Article \#30160 (2011), http://www.searchanddiscovery.com/pdfz/ documents/2011/30160schenk/ndx_schenk.pdf.html?q=\%25 2BauthorStrip\%253Aschenk+authorStrip\%253Aoliver.

Stroud, John, and Sonnenberg, S.A., 2011, The role of the Lower Lodgepole Formation in the Bakken Petroleum System, Billings Nose, North Dakota, chap. 12 of Robinson, J.W., LeFever, J.A., and Gaswirth, S.B., eds., 2011, The Bakken-Three Forks Petroleum System in the Williston Basin: Denver, Colo., The Rocky Mountain Association of Geologists, ISBN 0-933979-32-0. [Also available on CD-ROM and at http://archives.datapages.com/data/ rocky-mtn-geologist-pubs/data/002/002001/pdfs/1.pdf.] 
U.S. Department of the Interior (DOI), 2008, The National Atlas of the United States of America, accessed in 2008 at http://www.nationalatlas.gov/.[Superseded by The National Map, September 30, 2014, available at http://nationalmap.gov/.]

U.S. Energy Information Administration (EIA), 2012a, Independent statistics \& analysis, frequently asked questionsHow much oil does the United States consume per year?: U.S. Department of Energy, accessed December 11, 2013, at $h$ ttp://www.eia.gov/tools/faqs/faq.cfm? $i d=33 \& t=6$. Last updated November 15, 2012.

U.S. Energy Information Administration (EIA), 2012b, Independent statistics \& analysis-International Energy Statistics: U.S. Department of Energy, accessed December 11, 2013, at http://www.eia.gov/cfapps/ ipdbproject/IEDindex $3 . \mathrm{cfm} ? \mathrm{tid}=5 \&$ pid $=53$ \&aid $=1$.

U.S. Energy Information Administration (EIA), 2013, Independent statistics \& analysis - Petroleum \& other liquids, Drilling productivity report, release date December 9, 2013, accessed December 11, 2013, at http://www.eia.gov/ petroleum/drilling/\#tabs-summary-2.

U.S. Geological Survey, 2013, Energy Resources Program website: U.S. Geological Survey, accessed on December 12, 2013, at http://energy.usgs.gov/OilGas/ AssessmentsData/NationalOilGasAssessment.aspx.

U.S. Geological Survey Bakken-Three Forks Assessment Team, 2013, Input-form data for the U.S. Geological Survey assessment of the Devonian and Mississippian Bakken and Devonian Three Forks Formations of the U.S. Williston Basin Province, 2013: U.S. Geological Survey Open-File Report 2013-1094, 70 p., http://pubs.usgs.gov/ of/2013/1094/.

U.S. Geological Survey Bighorn Basin Province Assessment Team, 2010, Petroleum Systems and Geologic Assessment of Oil and Gas in the Bighorn Basin Province, Wyoming and Montana: U.S. Geological Survey Digital Data Series 69-V, 8 chaps, pages variable, http://pubs.usgs.gov/ $d d s / d d s-069 / d d s-069-v /$.

U.S. Geological Survey Hanna, Laramie, and Shirley Basins Province Assessment Team, 2007, Petroleum systems and geologic assessment of undiscovered oil and gas, Hanna, Laramie, and Shirley Basins Province, Wyoming: U.S. Geological Survey Digital Data Series 69-K, http://pubs.usgs. gov/dds/dds-069/dds-069-k/.
U.S. Geological Survey Oil and Gas Assessment Team, 2013, National Oil and Gas Assessment 2013 assessment updates, National Oil and Gas Assessment Summary Maps/Tables: U.S. Geological Survey, Energy Resources Program, accessed December 12, 2013, at http://energy.usgs.gov/ OilGas/AssessmentsData/NationalOilGasAssessment/ AssessmentUpdates.aspx.

U.S. Geological Survey Oil and Gas Assessment Team, 2012, Variability of distributions of well-scale estimated ultimate recovery for continuous (unconventional) oil and gas resources in the United States: U.S. Geological Survey Open-File Report 2012-1118, 18 p., http://pubs.usgs.gov/ of $/ 2012 / 1118 /$.

U.S. Geological Survey Oil Shale Assessment Team, 2011, Oil shale resources of the Eocene Green River Formation, Greater Green River Basin, Wyoming, Colorado, and Utah: U.S. Geological Survey Digital Data Series 69-DD, 6 chaps., pages variable, http://pubs.usgs.gov/dds/dds-069/ $d d s-069-d d /$.

U.S. Geological Survey Southwestern Wyoming Province Assessment Team, 2005, Petroleum systems and geologic assessment of oil and gas in the Southwestern Wyoming Province, Wyoming, Colorado, and Utah: U.S. Geological Survey Digital Data Series 69-D, http://pubs.usgs.gov/dds/ $d d s-069 / d d s-069-d /$.

U.S. Geological Survey Uinta-Piceance Province Assessment Team, 2003, Petroleum systems and geologic assessment of oil and gas the Uinta-Piceance Province, Utah and Colorado: U.S. Geological Survey Digital Data Series 69-B, http://pubs.usgs.gov/dds/dds-069/dds-069-b/.

Wallace, L.G., and Roen, J.B., 1989, Petroleum source rock potential of the Upper Ordovician black shale sequence, northern Appalachian Basin: U.S. Geological Survey OpenFile Report 89-488, 66 p. [Also available at $h t t p: / / p u b s$. er.usgs.gov/publication/ofr89488.]

Whidden, K.J., Anna, L.O., Pearson, K.M., Lillis, P.G., Charpentier, R.R., Cook, T.A., Klett, T.R., Pollastro, R.M., Dubiel, R.F., and Schenk, C.J., 2012, Assessment of undiscovered oil and gas resources in the Paradox Basin Province, Utah, Colorado, New Mexico, and Arizona, 2011: U.S. Geological Survey Fact Sheet 2012-3031, 4 p., http://pubs.usgs.gov/fs/2012/3031/. 
Manuscript approved January 15, 2015

Prepared by the USGS Science Publishing Network Publishing Service Centers (PSC)

Edit and cartographic layout by L.J. Binder, Denver PSC Layout Caryl J. Wipperfurth, Raleigh PSC

For more information concerning this report, contact:

Center Director, USGS Central Energy Resources Science Center Box 25046, Mail Stop 939

Denver, CO 80225

(303) 236-1647

Or visit the Central Energy Resources Science Center website at: http://energy.usgs.gov/ 
